\title{
POST-NATIONAL IDENTITY OF THE PROTAGONISTS IN THE NOVELS BY MYROSLAV DOCHYNETS
}

\author{
Olena Ishchenko \\ Postgraduate Student at the Department of Ukrainian Language and Literature, \\ Sumy State Pedagogical University named after A. S. Makarenko, Ukraine \\ e-mail: HeleneIshchenko@ua.fm, orcid.org/0000-0001-9274-8566
}

\section{Summary}

The article is devoted to the study of the post-national identity of the protagonists in the novels Centenarian. Confession on the pass of the spirit, Svitovan. Studies under the tent of the skies, Well-Digger. Diary of the richest resident of Mukachevo dominion, Highlander. Waters of our Lord's riverbeds, Maftey. Book written with a dry pen by a contemporary Ukrainian author M. Dochynets. It is proved that the deep rooting of M. Dochynets' protagonists in national culture and traditions does not deny the possibility of intercultural and interethnic dialogue, which creates a basis for the formation of post-national identity of Vichnyk / Svitovan, Well-Digger, Highlander, Maftey. Tolerance in relation to representatives of different nationalities, religions, worldviews, appeal to the cultural heritage of Antiquity, Renaissance ideas and imitation of the Christian tradition as characteristic features of the European identity of the protagonists of the writer are singled out and analyzed.

The article uses an interdisciplinary approach relevant to modern literary discourse, which allows to use the achievements of philosophy, sociology, psychology, culturology for the analysis of the literary text (interpretation of the characrer concept, definition of problem-thematic range, analysis of plot-compositional level, etc.). The author is convinced that the involvement of an interdisciplinary approach in the study of artistic understanding of the problem of post-national identity in the novels by $\mathrm{M}$. Dochynets will help fill gaps in the study of the writer's work and open prospects for further studies.

Keywords: national identity, post-national identity, European identity, life philosophy of the character, protagonist, novel.

DOI: https://doi.org/10.23856/3844

\section{Introduction}

With the formation of the European Union at the beginning of the XXI century, the problem of forming a 'pan-European worldview and pan-European value system' (Alonzi, 2018: 142), which contributed to the emergence of modern scientific discourse attempts to rethink the concept of 'national identity' and 'postnational identity' (U. Beck, C. Calhoun, G. Delanty, M. J. Hatch, R. Holton, S. Ivic, T. M. Nunn, S. Sassen, etc.). The postnational project of the German philosopher and sociologist J. Habermas became important for understanding the problem. In the work Involvement of another. Essays on political theory (2001) notes the ability of individuals, despite the 'mutual alienation', to be in solidarity, subject to the recognition and observance of established constitutional principles (Habermas, 2001: 216). There is talk of the emergence of post-national citizenship and, as a consequence, post-national identity and its forms (Delanty, 1997: 301). Gabermas' ideas opened up prospects for discussion and further research (studies by D. Castiglione, S. Calhoun and others). 
Following the leading tendencies of modern scientific discourse, at the end of the XX beginning of the XXI century the discourse of national identity with a clear postcolonial vector was actualized in Ukrainian literary criticism, which is explained by historical and socio-political factors. S. Andrusiv in The Modus of National Identity: The Lviv Text of the 1930s (2000) defines 'national' as a superpersonal force 'the desire of individuals to jointly create the textual body of their culture, to tell themselves and the world in their own language stories about their past and present-future. In a word, national is culture' (Andrusiv, 2000: 27). M. Ivanyshyn is convinced that this interpretation of the term 'national' is analogous to the concept of 'national identity' (Ivanyshyn, 2014: 48). Important for the formation of the theory of national identity in Ukrainian literary criticism were the works of O. Vertiy Folk sources of national identity of Ukrainian literature 70-90s of the XIX century (2005), U. Marynenko Mission: problems of national identity in Ukrainian prose 40-50s of the XX century century (2004), V. Morents National Ways of Poetic Art Nouveau of the first half of the twentieth century: Ukraine and Poland (2001), L. Senyka Novel of resistance. Ukrainian novel of the 20s: the problem of national identity (2002), N. Shumylo Under the sign of national identity. Ukrainian fiction and literary criticism of the late nineteenth - early twentieth century (2003) and others. Scholars focus on the study of artistic reproduction of national, postnational, postcolonial, European identity of the character, the impact of globalization on his consciousness, the specifics of modeling ethnic images, the specifics of reproduction of national memory and the peculiarities of forming images Own / Alien / Different, etc.

Despite the fact that in modern literary studies the scientific reception of the work of the modern Ukrainian writer M. Dochynets (famous works of M. Vaskiv, S. Velychko, L. Horbolis, S. Kovpik, O. Talko, etc.) has become relevant, the problem of post-national identity in his prose remains unnoticed by researchers. The purpose of the article is to analyze the specifics of the artistic reproduction of the post-national identity of the protagonists in the novels Centenarian. Confession on the pass of the spirit, Svitovan. Studies under the tent of the skies, Well-Digger. Diary of the richest resident of Mukachevo dominion, Highlander. Waters of our Lord's riverbeds, Maftey. Book written with a dry pen (the author of this article has already explored the problem of national identity in the prose of $\mathrm{M}$. Dochynets, so in this paper the focus is on post-national identity (Ishchenko, 2016, 2017)). The realization of the goal requires the solution of the following tasks: 1) to determine the post-national orientation of the philosophy of the M. Dochynets' protagonists; 2) to analyze the characteristic features of European identity represented in the concept of characters, to determine its sources.

In M. Dochynets' prose, an important motivating factor and representative of the inner world of the heroes is the deep rootedness in the Ukrainian national culture and, at the same time, openness to other cultures, philosophical systems, religions, etc., which testifies to their national and postnational identity. Investigating the writer's prose, we use the proposed literary definition of L. Senyk's concept of 'national identity': 'upholding the political, cultural and spiritual rights of the nation, statehood as the only possible form of normal existence of the national community for its self-affirmation, vital activity and development' (Senyk, 2002). The term 'post-national identity' means a form of identity 'with a greater degree of commonality than national identity' (Linchenko, 2017: 84). Since the protagonists of the writer live in the modern borders of Ukraine in Europe, it is worth talking about the formation of their 'dominant form' of postnational identity - European (S. Sassen proposes a classification of forms of postnational identities, which distinguishes 1) European identity; 2) opposition associations or corporate professional groups; 3 ) migration associations (diasporas); 4) associations formed under the influence of universal solidarity (environmental groups, volunteers, etc.)) (Sassen, 2002: 282-283). 
We consider various studies of M. Gibernau, M. Krepon, P. Kraus, K. Eder, and others to be important for understanding the problem. G. Delanty rightly notes that European identity is 'a form of post-national understanding that finds its expression not only outside but also within national identities' (Delanty, 2005: 417). Thus, in modern humanities studies the idea of the absence of contradictions between national identity and post-national identity is widespread, the assertion of their interdependence is expressed (Linchenko, 2017: 79).

The author believes that the interdisciplinary research method chosen in the article will help to fill the gaps in the study of M. Dochynets' prose and will promote the integration of literary discourse into the interdisciplinary plane.

\section{National and postnational vector of philosophy of M. Dochynets' protagonists}

M. Dochynets' author's ideological and aesthetic approach to the image of a new type of character, who identifies himself as a Ukrainian and at the same time a European, agrees with the concept of J. Habermas relevant in modern humanities, according to which individuals can ignore (Habermas, 2001: 216). It should be noted that in the writer's prose the civic position and moral and ethical guidelines of the protagonists are in agreement with the author's. The author interprets the self-identification of Ukrainians as representatives of a single European community as a manifestation of national self-consciousness, considers the idea that united the nation ('This is Europe, we are Europeans, Europe is with us, we are in Europe' (Pelenska)).

Centenarian / Svitovan, Well-Digger, Highlander, Maftey in their monologues-confessions, instructions, dialogues with students comprehend topical issues of today and their impact on the inner world of man, among which the problem of European integration stands out. The protagonists are convinced that the most important task for modern Ukrainians is to fight the artificially instilled by the Soviet government ("in the Iron Age $<\ldots>$ imprisonment of the spirit, oppression of public will' (Dochynets, 2014: 221)) inferiority complex, the consequences of its destructive influence on the mental health of fellow citizens. For example, Andriy Voron emphasizes that it can be destroyed only by appealing to the national culture, rules of folk morality, traditions and by focusing on the European system of values, which is close to every Ukrainian. Emphasizing the ability of an individual to influence the fate of the state, the protagonist-narrator motivates the narrator to awaken an active civic position: 'The human soul is whole, complete. And as much will and spiritual strength she draws and carries in herself, so much power in her people. So much of his viability, the will to release' (Dochynets, 2014: 222).

The protagonists of $\mathrm{M}$. Dochynets are not indifferent to the fate of their compatriots and the future of their native land. Over the years of long and eventful life, they have formed their own life system, one of the main constants of which is the need to know their inner world, self-improvement, self-identification. No less important for Centenarian / Svitovan, Well-Digger, Highlander, Maftey was the desire to understand the eternal ontological issues, among which the leading one is the problem of finding one's place in the world, which is not possible without finding and preserving national identity. For example, Andriy Voron remembers how, traveling in his youth in Romania 'under the Transylvanian Alps', he visited the villages where his compatriots lived. The protagonist was pleasantly surprised that Ukrainians who have not lived in their homeland for a long time have not lost the national specifics of organizing their lives, ethnomental markers of behavior: 'Smoke from good wooden huts here smelled like my land. And the family conversation gripped my heart with sensitivity. Everything here was native, recognizable, ticklishly close. It was as if a dream had brought me back to my father's palace. It is as if these people were sown from the sky into other people's borders' 
(Dochynets, 2013: 155). Numerous travels, meetings with extraordinary personalities, physical and spiritual trials (escape from captivity, survival among the wildlife of the Black Forest and Siberian taiga, imprisonment) contributed to the formation of the original philosophy of the character, based on the idea of equality of all peoples and nations before God. 'No one is free to violate God's order, according to which each tribe has its own territory, language and will. No iron visor can block this for long. It is ground by rust' (Dochynets, 2014: 223). Andriy Voron, like other protagonists of $\mathrm{M}$. Dochynets, is convinced that a person must learn to adapt to any conditions, use the acquired knowledge and experience to serve others, only in this way can individual and national identity be preserved in a changing world. 'Wherever you are, you are at home. Because this world is for you. If you accept him as he is, the world will never be hostile to you. Because does a man want to be an enemy to himself ?!' Andriy Voron emphasizes (Dochynets, 2014: 63). Thus, the original philosophy of the writer's protagonists is based on the idea of the possibility of intercultural and interethnic dialogue.

In the novel Well-Digger. Diary of the richest resident of Mukachevo dominion is an artistically modeled image of a Ukrainian who, traveling to other countries and gaining experience, knowledge, skills and abilities, managed to achieve considerable wealth and use them to build his native Mukachevo. The writer emphasizes that the protagonist's wealth is a reward for many years of self-improvement, for unique professional skills and the desire to increase knowledge in various fields. 'If the world opened my eyes, poured oil into my head, and gave me money, then I must, I suppose, use it to the end. I must serve him' (Dochynets, 2016: 7). He convinces his compatriots of the need to overcome the complex of inferiority, the search for mental harmony, helps to achieve success in public life, contributes to the development of his native Mukachevo.

Thus, Andriy Voron, Well-Digger, Highlander, Maftey are convinced that the spiritual, political and economic development of our country is possible provided the combination of Ukrainian cultural heritage and experience in organizing all areas of human activity with the practice of other countries.

\section{European identity of the writer's characters}

The author of the article considers the interpretation of European identity as a recognition of the common European system of values, the sources of which are 'classical antiquity, Christianity, Renaissance and Enlightenment and based on tolerance, humanism and brotherhood, rights man ...' (Tyhomyrova, 2005: 57). It is the most promising for understanding the inner world of M. Dochynets' protagonists. Important is the author's vision of a modern hero, who, according to M. Dochynets, 'is close and understandable to us in spirit' (Pelenska), but endowed with the ability to think modernly, in a European way, in which there is a core of European democracy and pluralism, philosophy of pantheism, humane selfishness, accumulation of joy' (Dochynets, 2013: 140).

The M. Dochynets' protagonists are tolerant towards representatives of different nationalities, religions, worldviews, they have a sense of brotherhood towards other peoples (for example, Ovferiy from the novel Well-Digger. Diary of the richest resident of Mukachevo dominion notes: 'What to be angry at people who are not like you. God has a lot of everything. <...> But aren't there a few strange things? Am I not strange for someone?!' (Dochynets, 2016: 8-10)). Teachers and spiritual mentors of the writer's characters were representatives of different nationalities and religions: Yakut shaman Kukumyr, Chinese Chan Bao, Greek Zacharios, pharmacist from Romania George Vladascu. The character is grateful to each of them for gaining 
knowledge about the world around them and for the opportunity to join the spiritual and cultural heritage of their peoples through acquaintance with them. 'The mighty power of the people of the tribe has passed over me. And I went through them like a hair through a tow. I went around different places with an attentive eye and an ear focused on everything wise' Andriy Voron remarks (Dochynets, 2013: 254). The purpose of the character is to convey this knowledge to his compatriots.

The philosophical system of Centenarian/Svitovan, Well-Digger, Highlander, Maftey agrees with the main ideas of the Renaissance, among which the leading one is the appeal to Antiquity. For a long time engaged in self-education, the protagonists of M. Dochynets studied the works of famous philosophers of the past Plato, Aristotle, Seneca, etc., and this influenced the formation of worldview and way of thinking of the protagonists of the writer. For example, Andriy Voron considered Socrates to be especially close to him, 'whom the world also pushed into prison at the end of his life' (Dochynets, 2013: 103). The hero was struck by the strength of the sage's will, the ability not to lose human dignity, to defend his own position in the harsh conditions of imprisonment, the lack of fear of death, which Socrates considered a dream 'without dreams': 'He loved such moments of solitude. Then he plunged into concentration, as in a wave, and in the solemn silence began to sound an inner voice, which advised him how to do. Maybe this is the end, maybe this is the opposite - a good start' (Dochynets, 2013: 103). Centenarian admits that thoughts about the sage helped to overcome loneliness in the Black Forest, supported in the camps of Kolyma. The protagonist's familiarity with ancient Greek mythology and literature (Andriy Voron, a fan of Homer's Odyssey and Iliad) also emphasizes his erudition, desire for self-improvement, and desire to join the European cultural heritage.

Since the original philosophy of the M. Dochynets' protagonists focuses on the understanding of man as the greatest value in the world, it clearly traces the echo of the anthropocentrism and humanism characteristic of the Renaissance. Exploring the multifaceted inner world of the individual through self-knowledge, the folk sages of the writer emphasize the limitless possibilities of self-improvement, the need to comprehend the spiritual and physical beauty of man (Ishchenko, 2018). 'I, for example, from the useful and beautiful more often choose the beautiful. The heart prevails over the mind. Everything that is natural is beautiful. And as long as you notice and appreciate it, Nature helps you', Andriy Voron remarks (Dochynets, 2013: 165). It should be noted that the protagonists of M. Dochynets have a close and modern ('broad') interpretation of the concept of 'humanism' as a cultural and socio-political orientation 'to the highest value of man, human personality' (Encyclopedia of the History of Ukraine: In 5 vols, 2003: 253). The heroes of the prose writer repeatedly express their thoughts on the meaning of human life, its purpose, etc., proclaiming the humanistic idea of equality before God and the importance of freedom for each individual.

The behavior and statements of the M. Dochynets' protagonists indicate that their original philosophy is based on the Christian tradition. Particularly close to them is the idea of 'God's providence', the belief in the active influence of the Higher Power on human life: 'I got used to space and dissolved in time. I felt that some mysterious Hand was leading me through this world. And he foresaw that $\langle\ldots\rangle$ in fresh waters he would purify me, in the prophetic depths he would strengthen me and heal me in the sunny valleys with bitter herbs ... No eloquence will cover what I have experienced and lived, what I thank for the only one $<$.. $>$ I find and choose His love at every step and return it to Him as the most precious honey of my works' (Dochynets, 2016: 265). There is an echo of pantheism in the religious worldview of M. Dochynets' protagonists, since they were born and lived almost all their lives among the 
wildlife of the Carpathians, genetically related to it, consider it spiritual and omnipotent. They define the finding of harmony with nature as the highest good for man, which will allow him to draw strength from it for physical and spiritual trials: 'I lay down on the water, heard a rustle of sand at the bottom, - and he moved with sand under the tide. My body was warmed by the sun - and I myself became the sun, radiated light and warmth. $<\ldots>$ I was in everything, and everything was in me ...' (Dochynets, 2013: 247). The religious syncretism of the writer's protagonists was formed under the influence of pagan ideas, rules of folk morality and Christian tradition.

Given these facts, we can say that the European identity in the novels by M. Dochynets is artistically understood as an integral part of the concept of the character. Centenarian/Svitovan, Well-Digger, Highlander, Maftey adhere to the common European system of values, the sources of which are the classical heritage of Antiquity, the Renaissance, the Christian tradition, which indicates that the protagonists have a European identity.

\section{Conclusion}

In the novels Centenarian. Confession on the pass of the spirit, Svitovan. Studies under the tent of the skies, Well-Digger. Diary of the richest resident of Mukachevo dominion, Highlander. Waters of our Lord's riverbeds, Maftey. Book written with a dry pen is a type of character with deep roots in national culture and traditions and open to international dialogue. The post-national identity of the M. Dochynets' protagonists can be traced in the guidelines for European integration, the idea of equality of all people before God, the belief in the need to use foreign experience in all spheres of human life, etc.).

The original philosophical system of Andriy Voron, Well-Digger, Highlander, Maftey is based on the ideas of tolerant attitude to representatives of different nationalities, religions, worldviews, brotherhood, mutual respect. The protagonists of the writer emphasize that they feel that they belong to a single European community, because they live in modern Europe and follow the European system of values.

Further research might involve the study of artistic representation of types features of the artistic image of images Own / Alien / Different in the novels by M. Dochynets.

\section{References}

Alonzi, R. (2018). Politicheskaja identichnost' ES: novye paradigmy i starye problemy [EU political identity: new paradigms, old problems]. Modern Europe. № 6. 142-151. [in Russian] Andrusiv, S. (2000). Modus natsional'noji identychnosti: Lvivs 'kyi tekst 30-h rokiv XX stolittia [Modus of national identity: Lviv text of the 1930s of XX century]. [in Ukrainian]

Chervonenko, $V$. (2020). Myroslav Dochynets: Umogo geroja taki z prygody jak u Monte-Kristo [Myroslav Dochynets: My Character has the same Adventures as Monte Cristo]. [Electronic resource]. Retrieved from: https://www.zakarpattya.net.ua/News/116155-Myroslav-DochynetsU-moho-heroia-taki-zh-pryhody-iak-u-Monte-Kristo. [in Ukrainian]

Delanty, G. (1997). Models of citizenship: Defining European identity and citizenship. Citizenship Studies. 285-303. [in English]

Delanty, G. (2005). The Idea of a Cosmopolitan Europe: On the Cultural Significance of Europ eanization. International Review of Sociology. Vol. 15, № 3. 405-421. [in English]

Dochynets, M. (2013). Vichnyk. Spovid'na perevali duhu [Centenarian. Confession on the pass of the spirit]. Mukachevo: Karpats'ka Veza. [in Ukrainian] 
Dochynets, M. (2016). Krynychar. Dijarijush naibagatshogo cholovica Mukachivs 'koji dominiji [Well-Digger. Diary of the richest resident of Mukachevo dominion]. Mukachevo: Karpats 'ka Veza. [in Ukrainian]

Dochynets, M. (2014). Svitovan. Shtudiji pid nebesnyn shatrom [Svitovan. Studies under the Tent of the Skies]. Mukachevo: Karpats'ka Veza. [in Ukrainian]

Dochynets, M. (2013). Svityl'nyk slova [Lamp of the Word]. Mukachevo: Karpats'ka Veza. [in Ukrainian]

Entsiklopedia istorii Ukrajiny: v 5 tomah. (2003). [Encyclopedia of the History of Ukraine: In 5 vols.]. Editor.: VA Smoliy et al. Kyiv: Naukova Dumka. Vol. 2: G-D. [in Ukrainian]

Ivanyshyn, M. (2014). Teorija natsional'noji identychnosti v ukrajins 'komu literaturoznavstvi: conseptual'ni pryntsypy ta ideji [The Theory of National Identity in the Ukrainian Literary: a Conceptual Principles and Ideas]. Youth and Market. № 3. 45-51. [in Ukrainian]

Ishchenko, O. (2018). Hudoznie osmyslennia fenomenu krasy v romanah Myroslava Dochyntsia: filosofs 'kyi aspect [Artistic Comprehension of the Phenomenon of Beauty in the novels by Myroslav Dochynets: philosophical aspect]. International scientific-practical conference "Roses and grapes: the phenomenon of aesthetic and pragmatic in literature and culture»: a collection of scientific materials of the conference (Berdyansk, September 27-28, 2018). Berdyansk: BSPU. 76-78. [in Ukrainian]

Ishchenko, O. (2016). Natsional'na identychnist' geroya romaniv Vichnyk ta Svitovan Myroslava Dochyntsia [The national identity of the character in novels Centenarian and Svitovan by Myroslav Dochynets]. Development strategies and priority tasks of philological sciences: Proceedings of the All-Ukrainian scientific-practical conference (Zaporizhzhya, December 23-24, 2016). Zaporizhzhya: Classical private university. 9-12. [in Ukrainian]

Ishchenko, O. (2017). Problema natsional'noji identychnosti u tvorchosti Myroslava Dochyntsia [The problem of national identity in the creative works by Myroslav Dochynets]. Taurian Philological Readings: Proceedings of the International Scientific Conference (Kyiv, January 27-28, 2017). Kyiv: Tavriya National University after V. I. Vernadsky. 16-19. [in Ukrainian]

Habermas, J. (2001). Vovlechenie drugogo. Ocherki politicheskoy teorii [Involvement of another. Essays on political theory]. Tran slated from German. St. Petersburg: Nauka. [in Russian]

Linchenko, A. A., Syrov, V. N., Golovashyna, O. V. (2017). Problema postnatsional'noj identichnosti: $k$ istoriografii voprosa [The problem of post-national identity: to the historiography of the question]. Bulletin of Tomsk State University. № 419. 79-85. [in Russian]

Pelenska, O. (2020). «Evropa - natsional'na ideja, jaka objednala ukrajintsiv» - Dochynets [Europe is a national idea that united Ukrainians]. [Electronic resource]. Retrieved from: https://www.radiosvoboda.org/a/25200217.html. [in Ukrainian]

Sassen, S. (2002). Towards Post-National and Denationalized Citizen ship. Handbook of Citizenship Studies / ed. by Engin F. Isin, Bryan S. Turner. SAGE Publications Ltd., P. 277-291. [in English]

Senyk, L. (2002). Roman oporu. Ukrajins 'kyi roman 20-h rokiv: problema natsional'noji identychnosti [Novel of resistance. The Ukrainian novel of the 1920s: the problem of national identity]. Lviv: Academic Express. [in Ukrainian]

Tyhomyrova, E. B. (2005). Formuvannia evropeis 'koji identychnosti jak chynnyk evropeis 'koji integratsii [Formation of European identity as a factor of European integration]. Proceedings. Political science № 45. 56-60. [in Ukrainian] 